\title{
Una macabra fábula fantástica. Macario (Roberto Gavaldón, 1960) a partir de «El tercer invitado» (1950) de Bruno Traven
}

\author{
A fantastic macabre fable. Macario (Roberto \\ Gavaldón, 1960) from «The Third Guest» (1950) \\ by Bruno Traven
}

\author{
JuAn Agustín Mancebo Roca \\ Universidad de Castilla-La Mancha \\ Juan.Mancebo@uclm.es \\ ORCID ID: 0000-0003-4942-8879
}

\begin{abstract}
Resumen: Este trabajo hace un análisis comparativo entre el cuento «El tercer invitado» (1950) de Bruno Traven y su adaptación cinematográfica, Macario (1960), dirigida por Roberto Gavaldón. El artículo contextualiza el cuento del autor alemán respecto al relato de los hermanos Grimm, la enigmática figura del escritor, su particular relación con el mundo del cine y las diferentes adaptaciones cinematográficas de su obra literaria. Se hace un estudio de la producción de la película y el trasvase del relato a la pantalla en el que se analiza la adaptación del texto a partir de los planteamientos coincidentes y divergentes. Finalmente, se relaciona la adaptación con los referentes temáticos e iconográficos y los nexos e influencias sobre los que se elabora la película.
\end{abstract}

Palabras clave: Macario, Roberto Gavaldón, Bruno Traven, Gabriel Figueroa, muerte, cuento, cine, México.

\begin{abstract}
This work makes a comparative analysis between the story «The Third Guest» (1950) by Bruno Traven and its film adaptation Macario (1960) directed by Roberto Gavaldón. The article contextualizes the story of the German author respect to the story of the brothers Grimm, the author's enigmatic figure, his particular relationship with the world of cinema and the different cinematographic adaptations of his literary work. A study about the production of the film and the transfer of the story to the screen has been made, in which both coincidental and divergent approaches has been used to analyse the adaptation of the text. Finally, this adaptation has been related to the thematic and iconographic references as well as the connections and influences on which the film is made.
\end{abstract}

Key Words: Macario, Roberto Gavaldón, Bruno Traven, Gabriel Figueroa, death, story, cinema, Mexico. 
Juan Agustín Mancebo Roca

\section{INTRODUCCIÓN}

La actualidad de Macario (Roberto Gavaldón, 1960) está determinada por una serie de factores que la convierten en una de las filmaciones esenciales de la historia del cine mexicano. Su temática se inscribe en la profunda y compleja relación del mexicano con la muerte que aparece transversalmente a través de su imaginería y la relectura de lo popular. Una cultura que, por otra parte, refleja la hibridación entre los mitos prehispánicos y los mediterráneos aportados por la colonización española. La muerte, en ese contexto festivo, simboliza la vanidad de la vida, como observa Octavio Paz: «nuestras representaciones populares son siempre burla de la vida, afirmación de la nadería e insignificancia de la humana existencia» (1997: 80).

Macario se conceptualiza en la relación universal del hombre respecto a su destino. La película es la adaptación del cuento «El tercer invitado» (1950) de Bruno Traven, autor del que se tienen escasos y contradictorios datos y cuya obra está condicionada por el pesimismo, la fatalidad y una profunda desconfianza en el ser humano. El argumento de «El tercer invitado» no es original, sino que proviene de una fábula popular centroeuropea recogida por los hermanos Grimm a principios del siglo XIX que Traven adaptaría al contexto histórico novohispano.

La película hace una relectura del arquetipo cinematográfico sobre la personalización de la muerte adaptándola a una trama y a un folclore determinados, una referencia que el director utilizaría posteriormente en películas como El Gallo de Oro (1964) o Doña Macabra (1971). De hecho, una de las características esenciales de Macario es la proyección de una imagen nacional sostenida por una cuidadosa puesta en escena en la que destaca la plasticidad y la textura de la fotografía de Gabriel Figueroa.

Macario se convirtió en un éxito de taquilla y cosechó premios nacionales e internacionales, siendo la primera película mexicana nominada al Óscar de la Academia en la categoría de mejor película extranjera. Pese a ello, la película fue denostada por los críticos del país, que le achacaron su falta de espíritu crítico, su condescendencia y superficialidad, y que se trataba de un producto destinado a la exhibición en los festivales internacionales.

Pese a ser riguroso con el texto literario, el guion de Macario sugirió cambios que potenciaban el discurso fílmico, desarrollando la acción sobre el Día de Muertos, eje que articula la fábula bifurcándola entre la realidad y la ficción. También es reseñable la influencia de los modelos cinematográficos europeos en los que se sustenta la película y que configuran un escenario precursor del realismo mágico latinoamericano que se estaba gestando en ese periodo. 


\section{LA MiSTERIOSA VIDA DE BRUNO TRAVEN}

«La historia de mi vida no decepcionaría a nadie. Sin embargo, se trata de un asunto privado que no quiero divulgar. No porque sea egoísta. Más bien porque deseo ser el único juez de mi propia causa». Con esas palabras el autor alemán respondía al requerimiento de información por parte de sus lectores en 1926. Un año después, la editorial Die Büchergilde justificaba la negativa a facilitar información del escritor por expreso deseo de este, que ejemplificaba una perseverante actitud que mantuvo toda su vida.

Bruno Traven (1882-1969) fue un escritor de difícil catalogación, ya que su itinerario biográfico fue complejo y él mismo trató de permanecer siempre en segundo plano. Sin demasiadas certezas que no sean las propiamente literarias, parece ser que su verdadero nombre fue Otto Feige y nació en 1882 en Schwiebus, Brandemburgo Oriental (Hauschild, 2012: 62). A lo largo de su vida emplearía varios seudónimos -hasta treinta- que había utilizado en los personajes de sus narraciones: Traven Torsvan, Hal Croves, Ret Marut, B. Traven - con el que firmó la mayoría de sus obras-o Bruno Traven. Sus actividades previas a la literatura no son muy conocidas. En su juventud fue ocasionalmente actor y un reconocido anarquista que participó en la breve República Popular Baviera, asignado al departamento de prensa (Munguía y Saavedra, 2010: 89) donde dirigiría la revista Der Ziegelbrenner -El Albañil- que determinó su vocación como escritor (Figueroa, 2008: 509). Acusado de alta traición, abandonó Alemania y se instaló en México, donde naufragó en un barco de la muerte en el puerto de Tampico en 1924.

Traven comenzó a escribir relatos y novelas desde su llegada a México. Originalmente lo hacía en alemán e inglés, enviando sus manuscritos a editoriales europeas. Sus novelas triunfaron inmediatamente, se tradujeron a cuarenta idiomas y vendió más de treinta millones de ejemplares (Hauschild 2012: 54). Pese a su éxito, guardó celosamente su intimidad, manteniendo que lo relevante era su obra y no su vida. Pensaba que un autor que era reconocido «desperdiciaba su herramienta más importante. El poder para observar y registrar la realidad con honestidad y claridad» (Figueroa, 2008: 519).

John Huston, que lo trataría a partir de 1946, mantenía que «era un personaje misterioso. Se había aislado de la sociedad y vivía en algún lugar apartado en México. Su editor en Nueva York, Alfred A. Knopf, envió una vez un emisario para localizarle, pero, aunque concertaron una cita, el esquivo autor no apareció» (Huston, 1998: 186). De hecho, el director norteamericano nunca supo muy bien quién era, pese a coincidir con Hal Croves. A este respecto relataba: 


\section{Juan Agustín Mancebo Roca}

Todo el mundo hablaba del misterio de B. Traven. En 1948 una revista mexicana envió a dos reporteros a espiar a Croves en un intento de comprobar los hechos. Le encontraron al frente de un pequeño almacén al borde la jungla, cerca de Acapulco [...] entraron forzando la puerta y registraron su escritorio. En el escritorio había varios manuscritos firmados por B. Traven y pruebas de que Croves utilizaba otro nombre: Traven Tornsvan. Al parecer, Hal Croves y Traven eran el mismo hombre, después de todo. Posteriores investigaciones han descubierto que tenía un cuarto nombre: Ret Marut, un escritor anarquista y antibelicista que desapareció en Alemania en 1922 (Huston, 1998: 195).

Al igual que Huston, el director Alfredo Crevenna conoció al supuesto representante de Traven en el rodaje de La rebelión de los colgados. Crevenna observó que Croves hablaba alemán y cuando le inquirió, Traven le pidió que le guardara el secreto: «tengo mis razones para guardar mi incógnito, le suplicaría a usted no dijera lo que escuchó, se lo prometí y nunca lo he hecho [...] me acuerdo que él me envió de París, de Alemania y de Italia, recortes de críticas de la película y cosas por el estilo, así fue como conocí a Traven» (Munguía y Saavedra, 2010: 94).

Su carácter huidizo no hizo más que aumentar su leyenda. Vila-Matas escribe que «fue la auténtica expresión de lo que conocemos por escritor oculto», un caso relevante, «para algunos, el hombre que decía llamarse B. Traven era un novelista norteamericano nacido en Chicago. Para otros, era Otto Feige, escritor alemán que habría tenido problemas con la justicia a causa de sus ideas anarquistas. Pero también se decía que en realidad era Maurice Rethenau, hijo del fundador de la multinacional AEG, y también había quien aseguraba que era hijo del káiser Guillermo II» (Vila-Matas, 2002: 211-217). Existe otra leyenda narrada por Gabriel Figueroa que identificaba a Bruno Traven con Esperanza López-Mateos. Se pensaba que Traven era un seudónimo que ella utilizaba para escribir, aunque realmente era su traductora al español, representante de sus derechos en América Latina y hermana de Adolfo López-Mateos, presidente de México entre 1958 y 1964 (Figueroa, 2005: 123-124; Isaac, 1993: 91-92).

Pese a vivir aislado en diferentes puntos de la geografía mexicana residió en Chiapas, Acapulco y la Ciudad de México, entre otros-, es paradójica la gran cantidad de fotografías que se le hicieron, algo extraño en alguien que fue considerado el virtuoso de las desapariciones (Hauschild, 2012: 66). Por otra parte, frecuentó a gran parte de los artistas mexicanos y foráneos más importantes de la época, los fotógrafos Tina Modotti, Edward Weston y el citado cinefotógrafo Gabriel Figueroa, así como a los pintores Frida Kalho, Diego Rivera y David Alfaro Siqueiros, con los que compartió inquietudes artísticas y afinidades políticas, ya que la mayoría pertenecían al Partido Comunista Mexicano. 


\section{TRAVEN Y SUS ADAPTACIONES CINEMATOGRÁFICAS}

Bruno Traven fue un apasionado del cine y de lo que lo rodeaba. Tuvo muy en cuenta las diferentes industrias en las que su obra podía ser adaptada, obrando a favor o en contra de la venta de derechos si no estaba convencido de que la filmación tendría buena financiación y se rodaría con solvencia. Por ejemplo, rechazó las primeras tentativas de Figueroa para adquirir los derechos de su obra en 1937 alegando la falta de medios de la industria cinematográfica mexicana (Figueroa 2005: 122-123; Isaac, 1993: 91). También escribió memorándums para dar indicaciones a los directores sobre localizaciones y formas de trasladar sus historias. Esa meticulosidad con respecto a la adaptación de sus novelas trascendía al interés que sentía por las estrellas del celuloide, como atestigua la anécdota de su fascinación por Lupe Tovar, de la que se decía que estuvo siempre enamorado. El escritor insistió en conocerla y quedó con ella en una playa pública de Acapulco. Tovar acudió a la cita, pero no así Traven, que se limitó a observar a la actriz desde la distancia como luego le indicaría en una carta (Isaac, 1993: 99).

La adaptación más conocida de Traven fue El Tesoro de Sierra Madre (The Treasure of the Sierra Madre, John Huston, 1948), basada en su novela homónima Der Schatz der Sierra Madre (1927). La novela fue sugerida a los estudios Warner Brothers por el productor Paul Kohner, que compró los derechos del libro en 1941. Encomendada a John Huston, director y autor empezaron a escribirse ese año, pero la guerra pospuso la producción. En 1946 se reanudó el contacto epistolar entre ambos y el escritor le hizo sugerencias para la película, llegándole a enviar un guion adaptado, aunque el texto definitivo fue de Huston. La participación del autor en la producción no se limitó a sugerir que fuera localizada en determinados puntos de la geografía mexicana, sino que estuvo en el rodaje como observador bajo el seudónimo de Hal Croves, cuyo conocimiento de los matices de la historia hizo al equipo sospechar que se trataba del verdadero autor.

La filmación de El Tesoro de Sierra Madre no estuvo exenta de problemas, ya que el gobierno mexicano interrumpió el rodaje por la imagen denigrante que ofrecía del país. La producción se reanudaría por la intermediación de Diego Rivera y Miguel Covarrubias, localizándose en Tampico y en los espacios naturales de Durango, Coatepec de Morelos y San Miguel de Chichimequillas, en la que fue la primera gran producción norteamericana rodada parcialmente fuera de los Estados Unidos.

El éxito de crítica y público fue enorme y se vio refrendado por tres premios Óscar de la Academia de Hollywood y tres Globos de Oro. A partir de ese momento Traven observó las enormes posibilidades del cine e inició una carrera como guionista en detrimento de su producción novelística. 
Además de El Tesoro de Sierra Madre, previamente a Macario se adaptaron otras obras del autor alemán como La rebelión de los colgados (Alfredo Crevenna y Emilio Fernández, 1954) -la película tuvo otra versión de Juan Luis Buñuel en 1987 de la Cooperativa Río Mixcoac para Europa (Munguía y Saavedra, 2010: 88) - y Canasta de cuentos mexicanos (Julio Bracho, 1955). La rebelión de los colgados era una apología de la libertad individual y trataba sobre las revueltas de los campesinos desde una perspectiva anarquista. A la ya de por sí polémica temática, se unió la condición de que no hubiera alteraciones en el guion, lo que pudo motivar el abandono por problemas con el productor de Emilio Fernández (Monsiváis, 1993: 172). Debido a la presión sindical la película fue concluida por Alfredo B. Crevenna. Pese al problemático rodaje la película fue un éxito, aunque mostraba escenas muy crudas que impidieron una mejor distribución internacional. Canasta de cuentos mexicanos, producida por José Kohn y protagonizada por Arturo de Córdoba, María Félix y Pedro Almendáriz, adaptaba tres relatos de los diez que contenía el libro de Bruno Traven: «Una solución inesperada», «Canasta» $\mathrm{y}$ «La tigresa».

La situación europea tras la Primera Guerra Mundial conformaba el argumento de El barco de la muerte (Das Totenschiff, Georg Tressler, 1959), una coproducción de la empresa alemana UFA y José Kohn, que adaptaba el libro homónimo publicado en 1927. Protagonizada por Horst Buchholz, Mario Adorf y Elke Sommer, era la historia autobiográfica que relataba la experiencia del escritor en un barco tripulado por parias, prófugos y asesinos indocumentados. La película es la menos conocida de sus adaptaciones, ya que tuvo problemas de derechos de autor y no pudo ser distribuida fuera de Alemania.

Las inclinaciones políticas de Traven y Roberto Gavaldón (1909-1986) llevaron al director a dirigir otras dos películas basadas en argumentos del escritor: Rosa Blanca (1961) y Días de otoño (1962). En cuanto a la primera, Traven y Josef Wider habían intentado realizar una coproducción germano-mexicana en 1958. Finalmente, el proyecto lo rodaría Gavaldón con dirección fotográfica del omnipresente Gabriel Figueroa. Protagonizada por Ignacio López Tarso, la filmación fue muy controvertida, ya que «fue realizada en tono de epopeya nacionalista y ubicada en la época previa a la expropiación petrolífera decretada en 1938 por Lázaro Cárdenas» (Vega Alfaro, 2019: 131). La película, muy crítica con la política imperialista de los Estados Unidos, fue censurada por la Secretaria de Gobierno, estrenándose finalmente en 1972 bajo el mandato de Luis Echevarría.

Días de otoño estaba relacionada con El tesoro de Sierra Madre, ya que Traven había tenido una buena experiencia con el productor Paul Kohner y le redactó un libreto para su mujer, la actriz Lupe Tovar, basado en su atípico cuento «Frustración». Finalmente, los papeles principales fueron 
para la dupla protagonista de Macario, Ignacio López Tarso y Pina Pellicer, en la que fue la última adaptación en vida del escritor.

Dos años después de la muerte de Traven se filmó Puente en la selva (Francisco Kohner, 1970). En 1958 el escritor había cedido los derechos a Gabriel Figueroa y el director Fred Zinnemann se mostró interesado en el proyecto, pero finalmente lo desechó (Munguía y Saavedra, 2010: 93). Puente en la selva fue, finalmente, una producción norteamericana protagonizada por John Huston, Charles Robinson, Katy Jurado, Chelena Luján - viuda de Traven- y Lupe Tovar, y fue filmada en diversas localidades de Chiapas - una de las regiones favoritas del escritor-, como la selva Lacandona, Tapachula y el río Huehuetán.

\section{3. «EL TERCER INVITADO»}

El cuento original fue escrito en inglés con el título «The Healer» («El sanador») y fue publicado en alemán como «Der Dritte Gast» por la editorial Die Büchergilde de Zürich en 1950. En 1953 fue publicado en Nueva York con el título «The Third Guest». En este sentido, hay confusión sobre el idioma en el que fue originalmente redactado, puesto que Bruno Traven escribía indistintamente en alemán e inglés, e incluso su viuda declararía en una entrevista en 1970 que el relato fue escrito en alemán (Wilson, 1975: 17). En 1960, se publicaría la versión española en México a cargo de la Compañía General de Ediciones (en la colección «Ideas, letras y vida») con el título de «El tercer invitado». El argumento no era propio, sino que estaba extraído de un cuento popular germano recogido en 1819 por los hermanos Jacob y Wilhelm Grimm, «La muerte madrina», también intitulado «El ahijado de la muerte» o «El carbonero y la muerte», que tiene más relación con el alemán «Der Gevatter Tod». El relato, por otra parte, tenía raíces hindúes y griegas, hasta llegar al folclore alemán y, de ahí, a la adaptación de los Grimm (Membrez, 2007: 30-34). En el cuento de los hermanos Grimm, la Muerte se convertía en el padrino del decimotercer hijo de un hombre muy pobre, tras haber sido rechazado por Dios y el Diablo. Para celebrarlo, la Muerte le concede a su ahijado la potestad de curar, aunque ese regalo contempla que tendrá reservado el mismo destino que el resto de la humanidad.

«El tercer invitado» narra la historia de un paupérrimo leñador con mujer y once hijos, que, pese a su extenuante trabajo, jamás puede llevar comida suficiente para su hambrienta familia. La única ilusión de Macario es poder comerse un guajolote - un pavo- sin tener que compartirlo con nadie. Una vez que su mujer hace posible su deseo, Macario se marcha al bosque para degustarlo tranquilo. En el bosque se le aparecen consecutivamente el Diablo, Dios y la Muerte para pedirle que comparta su comida. Macario se niega a convidar a los dos primeros y solo lo hace con el último, que, agradecido, le concede la facultad para curar gracias a 
un líquido milagroso. Pero en la dádiva también hay una condición: solo podrán sanar aquellos enfermos a los que la Muerte se le aparezca a Macario a los pies de la cama; cuando esta aparezca en el cabecero, no se podrá hacer nada, «pues mi presencia en ese sitio será señal de que el enfermo debe morir, sin que importen los esfuerzos que tú o muchos médicos hábiles hagan por arrebatármelo» (Traven, 2019).

Macario regresa a su aldea y comienza a realizar curaciones que lo sacan de la miseria. Convertido en un célebre curandero, adquiere una posición acomodada que levanta recelos por parte de algunos miembros de la comunidad, como el físico o el enterrador, que ven mermar sus negocios. Cuando su fama empieza a trascender, el virrey, la persona más poderosa de México, lo hace llamar para tratar a su hijo desahuciado. Cuando el mestizo intenta curarlo, la Muerte se le aparece en el cabecero de la cama. Pese a que Macario le suplica e intenta engañarla, no puede hacer nada por el muchacho y, tras su fracaso, el nativo es entregado a la Inquisición que lo acusa de brujería. El final de la historia es el propio sueño de Macario, que coincide con el momento en el que había compartido su comida con la Muerte. Un final que enlaza con la tradición romántica de la muerte dulce, «seguramente la muerte le sorprendió antes de que pudiera probar la otra mitad. A pesar de todo, parece que murió feliz» (Traven, 2019, s. pág.).

Por tanto, «El tercer invitado» es un relato perteneciente a una colectividad cultural que se inserta en otra muy distinta y mantiene el carácter original añadiéndole elementos propios de su folclore. Un relato universal que se traslada al contexto novohispano que Traven conocía por los años que llevaba residiendo y viajando por las selvas, pueblos y junglas de México.

\section{LA PRODUCCIÓN DE MACARIO}

La literatura fue uno de los pilares sobre los que se constituyó la obra cinematográfica de Roberto Gavaldón, que focalizó su atención en novelas y obras teatrales de calidad. Para la redacción de los guiones colaboró casi siempre con los autores de los textos y, si no le era posible, coescribía los argumentos con los escritores José Revueltas y Luis Alcoriza. La relación con Revueltas fue muy fructífera y este alcanzó sus mayores logros como argumentista y adaptador con el cineasta (Martínez Assad, 2015: 60). Gavaldón llegaría a trabajar con Gabriel García Márquez y Carlos Fuentes en la adaptación de la citada El Gallo de Oro de Juan Rulfo.

Antes de Macario, Roberto Gavaldón había construido una sólida carrera basada en adaptaciones como La Barraca (1945) y Flor de Mayo (1959) de Vicente Blasco Ibáñez, El socio (1946) de Genaro Prieto, La otra (1946) de Ryan James, La diosa arrodillada (1947) de Ladislao Fodor, A la sombra del puente (1948) de Maxwell Anderson, La casa chica (1950) de José 
Revueltas, Deseada (1951) de Eduardo Marquina, El rebozo de la soledad (1952) de Xavier López Ferrer, Las tres perfectas casadas (1953) de Alejandro Casona, Camelia (1954) de Alejandro Dumas, Sombra Verde (1954) de Ramiro Torres Septién, Después de la tormenta (1955) de Julio Alejandro, De carne somos (1955) de Eduardo Borrás, la trilogía Aquí está Heraclio Bernal, El rayo de Sinaloa y La ley de la sierra (1958) de Fausto Marín y Miércoles de ceniza (1958) de Luis Basurto.

Macario, como hemos señalado, era la adaptación del cuento de contexto colonial «El tercer invitado», cuyo guion fue escrito por el director junto al dramaturgo Emilio Carballido (1925-2008), que había realizado otros guiones para cine, destacando su colaboración con Julio Alejandro en Nazarín (Luis Buñuel, 1958). Parece ser que hubo alguna intervención del propio Traven, aunque en los títulos solo aparece como autor del relato.

La película fue una producción de CLASA Films Mundiales, empresa cinematográfica paraestatal que buscaba realizar un cine de calidad y que se acababa de separar de Nafinsa. José Hernández Delgado, presidente de esta, les ofreció la posibilidad de crédito y facilidades de pago a Figueroa, Gavaldón, María Félix y Manuel Barbachano, así como al resto de socios, para que pudieran hacerse cargo de la empresa (Saborit, 2007: 71).

Por tanto, Macario fue la primera producción de CLASA que coincidió con la crisis cinematográfica de la industria mexicana debido a la escasa calidad de las películas y a la sobrexplotación de formatos comerciales agotados. También fue una de las últimas grandes películas de la Edad de Oro del cine mexicano desarrollado en la década del milagro económico (1950-1960). En el rodaje colaboraron algunos de los mejores técnicos nacionales, destacando la dirección artística de Manuel Fontanals, el montaje de Gloria Schoemann y la dirección fotográfica de Gabriel Figueroa. En cuanto a este, Gavaldón le propuso filmar la película en color, pero el cinefotógrafo no se sentía con preparación suficiente para hacerla, aunque ya había rodado en color La doncella de piedra (Miguel M. Delgado, 1955). De hecho, Figueroa estaría interesado en ese momento en buscar el color del cine mexicano como lo hizo Rufino Tamayo en pintura o Luis Barragán en arquitectura, «pero la falta de laboratorios en México para revelar el material lo hizo imposible» (Orozco, 2019: 161).

En cuanto a la distribución de los papeles se pensó inicialmente en Pedro Armendáriz para el papel principal, aunque finalmente recayó en Ignacio López-Tarso (1925), actor con una sólida carrera teatral que estaba interviniendo en sus primeros papeles cinematográficos. Como señalan diversos estudios, es difícil concebir la película sin él, ya que su interpretación tiene un inigualable nivel de humanidad y empatía. Su participación consolidaría su relación con Gavaldón, así como su carrera 
como uno de los actores más relevantes del cine y la televisión mexicanos. A este respecto el actor indicaba:

Macario es muy importante y especial para mí. Fue la primera oportunidad estelar que tuve, me hizo ganar premios, me llevó de viaje a lugares que de otra manera no hubiera conocido, pero sobre todo me permitió encontrarme con Roberto Gavaldón, el director con el que me llegué a entender a la perfección, el que más influyó en mi carrera y mi desarrollo como actor de cine (Vega Alfaro, 2019:130).

El papel de la mujer sin nombre de Macario recayó en Pina Pellicer (1934-1964), que hacía bueno su rol como «La Mujer de los Ojos Tristes». En un ejercicio dramáticamente contenido, su papel es determinante para la acción, puesto que participa rompiendo el arquetipo femenino nativo de la época. El papel de la Muerte fue interpretado por el conocido actor chihuahuense Enrique Lucero (1920-1989), que lo abordó con una equilibrada dosis de sobriedad y humor.

Una de las características de los protagonistas fue la frescura de sus interpretaciones, que contrastaba con el carácter acartonado del resto de los actores. Esta diferencia acentuaba una de las particularidades esenciales del cine de Gavaldón, en el que «siempre estuvo latente la pulsión de trasparentar los contrastes, de evidenciar las paradojas de las élites ante las clases disímiles» (Astorga Riestra, 2019: 13), es decir, la confrontación entre los universos de los opresores y los oprimidos, en los que el propio lenguaje subraya la imposibilidad de superación y reconciliación de ambos mundos (Pérez Vázquez y Pellicer, 2006: 162).

El universo al que traslada la filmación es bastante similar al narrado por Traven. Entre las propiedades que apuntalan la visualidad de la película, figuran las cuidadosas localizaciones, que probablemente fueron sugeridas por el escritor alemán. La producción fue rodada en cinco semanas, entre el 7 de septiembre y el 9 de octubre de 1959, en Morelos (Puebla), Taxco (Guerrero), las lagunas de Zempoala (Morelos) y las grutas de Cacahuamilpa (Guerrero). La escena de las grutas es la más reconocida, un icono en el que la acción coincide con el final de la película alcanzando su clímax. A este respecto Figueroa recuerda:

En las grutas de Cacahuamilpa rodamos el final, es el lugar donde se supone que la muerte tiene su casa [...]. Pusimos tres mil velas; se dice fácil, pero hay que prenderlas una por una. Cuando ya tuve todo listo fuimos a filmar, ¡hasta los turistas nos ayudaron a encender velas! Quedó una secuencia preciosa (Monsiváis, 1994:184).

Estrenada en el cine Alameda de la Ciudad de México el 9 de junio de 1960, Macario estuvo en cartel catorce semanas, convirtiéndose en la 
película más taquillera de Roberto Gavaldón. Entre 1960 y 1963 logró diez premios nacionales y doce reconocimientos internacionales, la mayoría en la categoría de Fotografía: Valladolid, Boston, Santa Margarita Ligura, Vancouver, Edimburgo y Cannes. Además, fue la primera película mexicana en optar al Óscar en la categoría de Mejor película en lengua no inglesa en 1960. Bosley Crowther, en el New York Times del 28 de septiembre de 1961, reconocía sus valores culturales en detrimento de la producción norteamericana: «a nuestros cineastas rara vez se les ocurre un buen relato folclórico o hacen algo mejor que una caricatura animada como historia fantástica, así que son los cineastas extranjeros quienes deben mandarnos uno de vez en cuando» (1961, s. pág.).

Por el contrario, la recepción crítica nacional fue bastante fría y hostil en algunos casos. Se la acusaba de ser un producto prefabricado que ofrecía una imagen anquilosada y preciosista de México destinada a recibir premios en el extranjero. El crítico Emilio García Riera, en el número 12 de la revista El cine -agosto de 1960- editada por la UNAM, la calificó como «decorosamente mediocre» y «con una ausencia absoluta del mínimo rigor ideológico» (Pérez Vázquez y Pellicer, 2006: 163-164). También incidía en el problema del indígena: «ni qué decir que esa poetización de esa “condición eterna [del indio pobre]” resultaba por sí misma profundamente reaccionaria y conformista, pero quizá fuera aun peor que la realización neutra de Gavaldón tendiera a justificar la apariencia de falta de ideología por la simulación de la inocencia» (Membrez, 2007: 30).

En julio de 1960 José de la Colina escribía en Política que las actuaciones de los protagonistas estaban desaprovechadas debido al formalismo vacío del director. Hacía un duro alegato sobre la condición de los personajes: «si los hombres son humillados, todo es justo porque así lo quiere un orden superior a los hombres» (Membrez, 2007: 30); e incidía en la búsqueda del reconocimiento internacional más que en señalar la visión crítica de la problemática indígena.

Algo menos violenta fue la revista Esto en su crítica del 12 de junio de 1960, que la calificó como «película ambiciosa, exenta de lugares comunes y recursos fáciles, producida y realizada con mucha dignidad. Sobre todo, muy mexicana, tanto de tema como de ambiente y espíritu» (Pérez Vázquez y Pellicer, 2006: 169).

\section{Del TEXTO A LA IMAGEN: DE «EL TERCER INVITADO» A MACARIO}

La contextualización del texto literario en su traslación fílmica fue coherente comprendiendo que se trata de dos medios esencialmente distintos. A ello contribuyó la extensión y estructura del cuento, que era similar al de un guion cinematográfico. El texto de Gavaldón y Carballido equilibró la fábula de Traven en una historia en la que hay mayor 
coherencia entre las partes y en la que las acciones de los protagonistas determinan las consecuencias.

En el guion, por otra parte, se insertan variantes que refuerzan el discurso fílmico. La más destacada es la ambientación del Día de Muertos, a la que se da especial relevancia en la introducción y en las imágenes que lo describen, a diferencia del texto literario, en el que se menciona el día de difuntos como uno de los pocos en los que Macario consigue ganar más dinero. Previa a los créditos aparece una somera explicación del Día de Muertos, su particular iconografía y lo que significa en México. Ese proemio va a constituir el eje de la filmación, ya que articulará la historia desde el mundo real hasta su proyección a lo fantástico.

El siguiente segmento de la película nos presenta a la familia de Macario, que está formada por su mujer y cinco niños, mostrando la extrema pobreza en la que viven. Enfatiza la monotonía de la comida, que consiste en «frijoles negros, chile verde, tortillas, sal y té limón. La cena era siempre la misma, sin variación alguna» (Traven, 2019, s. pág.). Además, la cantidad es escasa y los niños esperan poder comer las exiguas sobras del padre. La idea del hambre de Macario y su familia adquiere una fisicidad que se traslada al espectador. El inicio del cuento manifestaba ese anhelo de poder comer hasta saciarse: «esta gran ilusión era la de poderse comer a solas, gozando de la paz en las profundidades del bosque y sin ser visto por sus hambrientos hijos, un pavo asado entero». A la vez, ese deseo eleva una plegaria que adquiere tintes premonitorios: «Oh, Señor -reza Macario en el libro-, si por lo menos una vez en mi pobre vida pudiera comerme entero un guajolote asado, moriría feliz y descansaría en paz hasta el día del Juicio Final» (Traven, 2019, s. pág.).

Macario no ve satisfecho su apetito y promete no volver a probar bocado. Y lo fantástico empieza a tomar cuerpo en el sueño del protagonista, operando como antesala de la muerte. En su sueño, Macario es un titiritero que maneja dos grupos de esqueletos diferenciados por ropas que denotan la riqueza de unos y la pobreza de otros. Mientras el grupo de los ricos se divierte, los pobres miran tras los barrotes, al igual que los hijos de Macario observaban las generosas ofrendas en el altar de Don Ramiro. Pero Macario conseguirá que los pobres accedan a la comida y su sueño se transforme en pesadilla cuando estos no dejen nada para él. Esta escena evoca a una onírica de Los olvidados (Luis Buñuel, 1950), fotografiada también por Figueroa: en el sueño de Pedro, el Jaibo, convertido en íncubo, le arrebata la comida que le ha ofrecido su madre. La escena de Macario concreta la metáfora social que sugiere al principio la película: pese a ser igual para todos, hay una muerte para los ricos y otra muy distinta para los pobres. También es una imagen premonitoria que anuncia que Macario no llegará a comerse el guajolote, ni siquiera la mitad, como apuntaba el texto literario original: «¿Qué puede hacer un 
mortal contra el destino? Nada. Tenía que sucumbir finalmente. Ya lo presentía. No hay escape posible. Hubiera podido gozar de gran ventura, pero el destino no lo quiso, y así debe ser» (Traven, 2019, s. pág.).

En la película hay un cambio relevante sobre el tono moral ejemplificado por la consecución del pavo. En el cuento, la mujer de Macario ahorra durante mucho tiempo para poder comprar el guajolote: «pudo hacerse del pavo más gordo que encontró en la plaza. Reventando de gozo y satisfacción lo llevó a su casa cuando los niños estaban ausentes y lo escondió» (Traven, 2019, s. pág.). Sin embargo, en la película lo roba como venganza cuando se niegan a pagarle los arreglos de la ropa, lo que determinará la fatalidad de los acontecimientos posteriores.

El siguiente segmento configura los encuentros sobrenaturales con el Diablo, Dios y la Muerte. El relato describe al Diablo (José Gálvez) vestido ostentosamente de charro, como traslada la filmación, algo que tuvo que ser explicado en el periplo internacional de la película, ya que los críticos no comprendían quién era. Dios (José Luis Jiménez) aparece como un anciano venerable cubierto de harapos. En cuanto a la Muerte, en el cuento no se hace referencia a su vestimenta, solo a su aspecto físico: «en su cara no quedaba rastro alguno de carne, todo era hueso, como sólo hueso eran las piernas y las manos del nuevo visitante» (Traven, 2019, s. pág.). De hecho, su apariencia confunde a Macario. Si en las representaciones tradicionales la Muerte lleva un reloj de arena, en el cuento porta un cronómetro inglés, gracias al cual reconoce que no llega tarde a sus citas. El autor alemán articula en ese punto un relato político antibélico y antimperialista que omite el film. En la película la Muerte es masculina, aparece vestida como un campesino criollo, con sombrero de paja, jorongo negro y sin ningún rasgo clásico que la identifique. Este recurso iconográfico provoca la familiaridad entre ambos, ya que, por su vestimenta, se encuentran en el mismo rango social.

De manera relajada, la Muerte le interroga sobre por qué ha compartido su comida y no lo ha hecho con los anteriores. La contestación de Macario es un recurso extraído del cuento, puesto que el mestizo sabe a quién convida y lo ha hecho para ganar tiempo: «Bien, compadre -contestó Macario-. En cuanto le vi comprendí que no me quedaba tiempo de comer ni una sola pierna y que tendría que abandonar el pavo entero. Cuando usted se aparece ya no da tiempo de nada. Así, pues, pensé: "Mientras él coma, comeré yo", y por eso partí el pavo en dos» (Traven, 2019, s. pág.).

Su generosidad y habilidad para esquivar su destino hacen que la Muerte le corresponda con un regalo. Esta hace brotar una fuente de agua que servirá para sanar a los enfermos. Además, también le indica que usará pronto ese nuevo don. En el cuento, la Muerte lo concibe como una broma para hacer menos pesada su carga: «habrás de saber, compadre, que 
alguna vez gusto de jugar bromas a los hombres. Bromas que no hieren a nadie y que me divierten haciendo que mi trabajo sea menos monótono, ¿comprendes?» (Traven, 2019, s. pág.). Pero también le indica que solo se curarán aquellos a los que se les aparezca a los pies de la cama, mientras que, si lo hace en el cabecero, le pertenecerán a ella.

La facultad de curar, como le ha pronosticado la Muerte, la experimenta con su propio hijo. A partir de ahí su fama no hará más que crecer. Macario sanará a la mujer de Don Ramiro (Mario Alberto Ramírez), el hacendado del pueblo, que observa en sus poderes curativos la posibilidad de enriquecerse también, por lo que estipulará una cantidad porcentual del dinero de los clientes que consiga para Macario. Macario continuará sanando a los pobres, pero su éxito despertará la envidia del médico local, que lo denuncia a las autoridades.

Macario será perseguido por soldados que destruirán las reservas de su líquido milagroso. El proceso incoado tiene tres partes: el interrogatorio, la prueba de su poder en los calabozos y, finalmente, el fallido intento de curar al hijo del virrey (Eduardo Fajardo). Pese a sus infructuosos esfuerzos por sanarlo y engañar a la Muerte «con movimiento resuelto, Macario tomó la cama y la hizo girar violentamente de manera que su antiguo huésped quedará parado a los pies» (Traven, 2019, s. pág.); esta permanecerá en el cabecero de la cama sellando el destino del niño, pues «sin duda alguna tenía órdenes de llevarse al chiquillo» (Traven, 2019. s. pág.).

Macario huye y retorna al bosque. Aquí el guion inserta la parte de la caverna de los hermanos Grimm que no aparece en «El tercer invitado», aunque estaría más que probablemente influida por Las tres luces de Fritz Lang, como veremos. Macario atravesará la gruta en cuya entrada había compartido su comida con la Muerte, donde la encuentra en una enorme cavidad llena de velas que representan las vidas de todos los hombres «mira, Macario -le indica-, esta es la humanidad, aquí ves arder las vidas tranquilamente. A veces soplan los vientos de la guerra, los de la peste, y las vidas se apagan por millares al azar: las altas, las pequeñas, las derechas, las torcidas». La Muerte le muestra la llama del hijo del virrey y la apaga. Macario quiere ver la suya convertida en una vela muy débil y pequeña. De nuevo, como ha sucedido en la cama del muchacho, intenta engañar a la Muerte, le arrebata la vela y huye. Pero no se puede burlar a la Muerte. Su destino está marcado.

Las llamadas de la Muerte se confunden con las de la mujer de Macario, que, junto a sus vecinos, lo buscan por el bosque. Lo encuentran ataviado con la misma ropa con la que salió de casa. Parece que está dormido, pero ha muerto y ni siquiera pudo terminar su guajolote. 
Una macabra fábula fantástica

\section{MACARIO EN LA TRADICIÓN CINEMATOGRÁFICA Y PICTÓRICA SOBRE LA MUERTE}

La temática de Macario es la muerte y la íntima relación del ser humano con el hecho absoluto que condiciona su existencia. Mito universal que se presenta en un contexto determinado, la película concibe la muerte como parte de la vida, en la que ambas son sagradas y no se puede comprender la una sin la otra. Macario reinterpreta el mito de la personificación de la muerte que resume y cierra esa tradición cinematográfica.

La Muerte había sido llevada a la gran pantalla en Las tres luces (Der müde Tod, Fritz Lang, 1921). Su traducción literal, La muerte cansada, hace justicia al relato elaborado por Lang, en el que la parca cumple una función indeseable de la que está hastiada. De hecho, Las tres luces tiene líneas argumentales similares a Macario: la idea de que no se puede vencer a la Muerte, de que el amor no justifica la extinción de la conciencia humana, y la impasibilidad de la parca ante su destino, del que no tiene escapatoria.

Estéticamente hay una más que evidente relación entre la poderosa puesta en escena de ambas películas. La primera, con un diseño de producción de estética neogótica y expresionista, respondía a una pulsión vinculada con la espiritualidad y la moral de la Europa protestante, concretamente de la Alemania luterana. La segunda, a partir de la iconografía popular que exaltaba los valores identitarios mexicanos. En los dos films se hacía una detallada revisión de la pintura del XIX y principios del XX, trasladando los elementos pictóricos a la configuración cinematográfica. En Las tres luces se reflejaba el romanticismo de Caspar David Friedrich y Alfred Rethel, el simbolismo de Arnold Böcklin y la consideración del expresionismo apocalíptico de Ludwig Meidner y el expresionismo sagrado de Emil Nolde. En Macario se trasladaban las preocupaciones de la Escuela Mexicana de Pintura, con el antecedente de la obra gráfica de José Guadalupe Posada (1852-1913) -y su mención explícita al arte popular-, así como a la pintura del Dr. Alt, Leopoldo Méndez y José Clemente Orozco.

La influencia de la película de Lang queda patente en la escena de la cueva de Cacahuamilpa, en la que la Muerte contempla las vidas de los mortales reflejadas en las velas de la gruta. Quizá Macario presenta una mayor carga onírica debido al refinamiento estético de la fotografía de Figueroa, que, si bien está determinado por una mirada expresionista, construye una textura que la identifica e iguala con el resto de la filmación.

Por otra parte, la influencia escandinava está presente a través de $E l$ séptimo sello (Det sjunde inseglet, Ingmar Bergman, 1957), algo que le achacó la crítica mexicana en sus recensiones sobre la película. El séptimo sello, que exorcizaba el terror patológico hacia la muerte que impulsó la filmografía del creador sueco, estaba influenciada por La carreta fantasma (Körkarlen, 
Victor Sjöström, 1921), que adaptaba la moralista novela de Selma Lagerlöf basada en una leyenda escandinava. Y de nuevo, la muerte aparece en el homenaje que Bergman le hace a Sjöström, convertido en el anciano profesor protagonista de Fresas salvajes (Smultronstället, 1957). A diferencia de los ensayos del sueco, la referencia a la muerte en la película mexicana es menos descarnada. La película de Roberto Gavaldón retrata el carácter que juega, burla y festeja la muerte para conjurar un miedo que, pese a ser un terror distinto, no deja de ser universal.

Los protagonistas de Bergman y Gavaldón interaccionan con la muerte para postergar su partida, lo que refleja la inteligencia de ambos protagonistas. El caballero Antonius Block (Max von Sydow) lo hace a través del ajedrez; Macario, en cambio, intenta posponer su destino compartiendo su comida. A diferencia del primero, en el film de Gavaldón no hay un interrogatorio sobre el más allá - que en el caso de Bergman, la Muerte (Bengt Ekerot) nunca resuelve porque no es su cometido-, simplemente existe una conversación animada en la que se tratan con familiaridad y en la que el campesino logra arrancar una sonrisa a la Muerte, lo que convierte la película en una «desenfadada fantasmagoría macabra» (Mino Gracia, 2007: 13).

La diversidad contextual remite a la universalidad del relato. El caballero Block retorna a casa en una Europa desolada por la peste y la guerra. Macario lo hace en el contexto colonial de la dominación española. Ambas reivindican las imágenes pretéritas como las danzas de la muerte, presentes en las manifestaciones medievales europeas y el culto a los muertos, síntesis del mundo europeo y prehispánico del país azteca.

La reivindicación del acervo popular prehispánico tenía un antecedente cinematográfico en el proyecto inconcluso iQue viva México! (Da zdravstvuyet Meksika!, Serguéi Eisenstein, 1930), que contenía gran parte de las imágenes que caracterizan el país cuando los mexicanos están buscando su referente. El director soviético reconocía que su interés por México comenzó cuando contempló fotos del Día de Muertos (Bergan, 2001: 252) y se sintió fascinado por una tierra arrasada capaz de producir una singular iconografía que sacralizaba la muerte para proyectarse en la vida (Eisenstein, 1988: 380). Al igual que en el tema de las fiestas -resulta contradictorio que un país tan triste tenga tantas y tan variadas celebraciones-, el pesimismo y el dolor se transustancian en coloridas imágenes y máscaras de la vacuidad -cómo no recordar su famoso retrato con la calavera de azúcar, bellísima y terrible celebración de la muerte-, de su arte popular, del folklore y de la vida.

A través de la fotografía de Eduard Tissé, Eisenstein corporeiza el drama mexicano llevándolo a una depuración estética que se convertirá en el modelo de los grandes directores de fotografía de la época dorada del cine patrio. El amor por la cultura mexicana del director soviético ha sido 
citado por Peter Greenaway en Eisenstein en Guanajuato (Eisenstein in Guanajuato, 2015), poniendo en valor esas referencias para articular y construir su historia.

La tradición cinematográfica de la muerte se complementa con la pintura y las manifestaciones populares mexicanas. Muchos de sus fotogramas se pueden comprender como elementos exentos, piezas con un alto grado estético, que conforman un gran mosaico, extensión y reflejo de la construcción nacional que propusieron por el influjo vasconcelista los muralistas mexicanos. Según José Vasconcelos, había que elaborar la identidad patria, estudiarla y difundirla, y nada mejor que la mirada de los pintores para servir a este propósito. Una disposición que pretendía ser original, pero que no era más que la traslación de los laboratorios de la vanguardia europea a México. Y, al igual que los vanguardistas del viejo continente, los artistas mexicanos van a buscar en su acervo cultural todo aquello que les identifica como pueblo y les diferencia de la tradición española, construyendo una imagen que reniega de la imposición cultural. A finales del XIX, los artistas europeos dirigieron su mirada a los mitos no occidentales y las vanguardias de principios del XX revisaron su pasado los cubistas, los expresionistas centroeuropeos y los primitivistas rusospara elaborar nuevas propuestas artísticas. Por extensión, ese comportamiento se mimetizó en el México postrevolucionario en la búsqueda de una imagen que identificara el país en el mundo contemporáneo empoderando lo vernáculo en sus artes visuales.

Por tanto, hay una fijación por lo popular y las manifestaciones de las distintas tribus originales de México. De ahí el redescubrimiento del arte popular, las calaveras de colores, las máscaras y los esqueletos que había mostrado la obra gráfica de José Guadalupe Posada, que, a su vez, había creado su icónica Catrina, la muerte presumida vestida de mujer pudiente. Herederos y renovadores de esa iconografía, José Clemente Orozco, Leopoldo Méndez y Fermín Revueltas reactivan esa imagen profundamente nacionalista que está presente en la obra de Gavaldón a través de la fotografía de Figueroa. Como mantenía Siqueiros, «puede decirse que Gabriel Figueroa es el hombre que ha sabido relacionar profundamente el análisis cinematográfico, la obra muralista que nosotros hemos realizado» (Vázquez Mantecón, 1996: 29).

Por tanto, Macario participa de esa estética deliberada en la que se genera una imagen artificiosa a partir de los iconos de la cultura. Una invención que también estuvo avalada por los espectadores, como bien ha señalado Carlos Monsiváis: «si inventan un país también llamado México lo hacen de acuerdo con el público que en las butacas recupera y reelabora lo acontecido en la pantalla» (2006: 442). 
Juan Agustín Mancebo Roca

\section{A MODO DE CONCLUSIÓN}

En la obra y la vida de Bruno Traven se involucran la literatura, el cine y la historia. En este sentido, «El tercer invitado» se configura como parte de las anteriores, es decir, es un relato transnacional adaptado a un contexto cultural que cristaliza en la adaptación cinematográfica de Roberto Gavaldón. El cuento y la película focalizarán el exotismo nativo a través de una fábula fantástica. Pero más allá del carácter sobrenatural, hay una profunda crítica sobre el papel de los desfavorecidos y su relación con las clases acomodadas en un contexto histórico extrapolable a la actualidad. Reproche que, por otra parte, traslada un sentimiento de decepción con los valores de la civilización presentes en los mundos de Traven y Gavaldón.

Macario plantea temas universales como la vanidad de la vida, la inutilidad de las posesiones materiales, los peligros del destino, los escasos momentos de felicidad y la relación del ser humano con lo Absoluto a través de la presencia angustiosa de la muerte. A diferencia de otros modelos cinematográficos, la película explora la íntima relación del mexicano con la muerte, cuyo temor hace que se burle y juegue con ella, la rechace y la haga suya como ninguna otra cultura lo ha hecho.

La película transcribe el carácter esencial del relato, ya que el mundo creativo de Traven estuvo mediatizado por el cine a partir de El tesoro de Sierra Madre. El escritor estaba presente en los rodajes, sugería ideas, intervenía en los guiones y trasladaba peticiones explícitas de localización, experiencias que se concretarían en la concepción de «El tercer invitado», que escribió, como gran parte de los textos de su última época, con la idea de que se pudiera adaptar a la gran pantalla.

Si el original hacía factible esa conexión entre literatura y cine, el guion de Gavaldón y Carballido fortalece el carácter esencialmente cinematográfico del texto. Además, Roberto Gavaldón, con la colaboración de Gabriel Figueroa, fue capaz de crear escenas muy precisas que articulan y potencian la historia. Imágenes que, a la vez, se alimentan de otras. Por un lado, la poderosa iconografía del Día de Muertos, que se readapta a partir de la lectura que hacen los muralistas y pintores mexicanos de la obra de Posada. Por otro, las influencias cinematográficas europeas, a partir de las lecturas de Fritz Lang e Ingmar Bergman, cuyo universo está muy presente en la película.

En Macario se materializan una serie de referentes mitológicos, literarios y artísticos que la convierten en una de las grandes referencias cinematográficas del hombre en relación con el misterio último de la vida; secularización del más allá que invita a la interrogación respecto al Absoluto. El mensaje del libro y su transposición fílmica remiten de nuevo a Octavio Paz, cuando escribía que en la muerte destella la vida «antes de desmoronarse y hundirse en la nada, se esculpe y se vuelve forma 
inmutable: ya no cambiaremos sino para desaparecer. Nuestra muerte ilumina nuestra vida» (1997: 75).

\section{Bibliografía Citada}

Arriaga BeníteZ, Juan Manuel (2019), «La construcción del significado en el cine: un análisis sobre Macario (1960)», Diseminaciones, 2/4, págs. 143-155 [En línea: http://diseminaciones.uaq.mx/index.php/ojs/article/view/55/34. Fecha de consulta: 30/04/2020].

Astorga Riestra, Paula (2019), «Roberto Gavaldón. Un devenir cinematográfico», en Q. Casas (ed.), Roberto Gavaldón, San Sebastián/Madrid, Festival de San Sebastián/Filmoteca Española, págs. 11-20.

BELINCHÓN, Gregorio (2019), «Roberto Gavaldón, la leyenda del cineasta olvidado», El País, 15.412 [En línea: https://elpais.com/cultura/2019/09/24/actualidad/1569312360_6 51163.html. Fecha de consulta: 29/04/2020].

Bergan, Ronald (2001), Serguéi Eisenstein, Una vida en conflicto, Barcelona, Alba.

Crowther, Bosley (1961), «The Screen: 'Macario': Folk Tale-Fantasy of Mexico in Premiere», The New York Times, 28 de septiembre de 1961 línea: https: / /www.nytimes.com/1961/09/28/archives/the-screenmacariofolk-talefantasy-of-mexico-in-premiere.html. Fecha de consulta: 05/04/2020].

Eisenstein, Serguéi M. (1988), Yo, memorias inmorales, México, Siglo XXI. FIGUEROA, Gabriel (2005), Memorias, México, Equilibrista/UNAM.

FigueroA, Gabriel (2008), «Recordando a B. Traven», Luna Córnea, 32, págs. 509-530.

Grimm, Jacob y Wilhelm (2016), «La muerte madrina», Textos.info [En línea: https://www.textos.info/hermanos-grimm/la-muertemadrina. Fecha de consulta: 30/04/2020].

HAUSCHILD, Jan-Christoph (2012), «El hombre que se inventó a si mismo: Otto Feige y sus seudónimos Red Marut y B. Traven (1882-1969)». Anuari de filología. Literatures Contemporànies, 2, págs. 53-68 [En línea: https://revistes.ub.edu/index.php/AFLC/article/view/5487. Fecha de consulta: 22/04/2020].

Huston, John (1998), Memorias, Madrid, Espasa.

ISAAC, Alberto (1993), Conversaciones con Gabriel Figueroa, Guadalajara, Universidad de Guadalajara.

Leyva, José M. y Mariana Riva (2007), El cine en México y el mundo. Cronología de Gabriel Figueroa, México, Fundación Televisa. 
Martínez Assad, Carlos (2015), «El cine de Revueltas», Revista de la Universidad de México, 132, págs. 60-65 [En línea: http://www.revistadelauniversidad.unam.mx/ojs_rum/index.php/r um/article/view/16525/0. Fecha de consulta: 04/05/2020].

MembreZ, Nancy (2007), «El peón y la muerte. El caso transnacional de Macario (1960)», Latinoamericana, 44, págs. 27-58 [En línea: http://www.scielo.org.mx/pdf/latinoam/n44/2448-6914latinoam-44-27.pdf. Fecha de consulta: 02/05/2020].

Mino Gracia, Fernando (2007), La fatalidad urbana. El cine de Roberto Gavaldón, México, UNAM.

Monsiváis, Carlos (1994), Gabriel Figueroa. La mirada en el centro, México, Porrúa.

Monsiváis, Carlos (2006), Imágenes de la tradición viva, México, UNAM.

Munguía, Jorge e Isis SAAvedra (2010), «Enigmas de Bruno Traven», Revista de la Universidad de México, 76, págs. 84-94 [En línea: http://www.revistadelauniversidad.unam.mx/ojs_rum/index.php/r um/article/view/1778/2781. Fecha de consulta: 22/04/2020].

Orozco, Héctor (2019), «Con los ojos de una cámara. Roberto Gavaldón y los fotógrafos de cine», en Q. Casas (ed.), Roberto Gavaldón, San Sebastián/Madrid, Festival de San Sebastián/Filmoteca Española, págs. 151-164.

PAz, Octavio (1997), El laberinto de la soledad y otras obras, Nueva York, Penguin.

Peña Martínez, Francisco (2014), Por un análisis antropológico del cine. Imaginarios filmicos, cultura y subjetividad, México, Navarra.

Pérez VÁzQuez, Reynol y Ana Pellicer (2006), Pina Pellicer, luz de tristeza (1934-1964), México, UNAM.

SAvorit, Antonio (2007), Gabriel Figueroa, México, Fundación Televisa.

Traven, Bruno (2009), La nave de los muertos, Barcelona, Acantilado.

Traven, Bruno (2019), Macario. Un cuento del México colonial, México, Libros de México (edición Kindle).

Traven, Bruno (2019), Canasta de cuentos mexicanos. México, Libros de México (edición Kindle).

Traven, Bruno (2020), El secreto de la Sierra Madre, México, Libros de México (edición Kindle).

VÁzQUEZ MANTECón, Álvaro (1996), «Los tres grandes eran cuatro», en E. Levín et. al. (eds.), Gabriel Figueroa y la pintura mexicana, México, Museo Carrillo Gil, págs. 29-38.

Vega Alfaro, Eduardo de la (2019), «Notas sobre la dupla artística Roberto Gavaldón-Ignacio López Tarso», en Q. Casas (ed.), Roberto Gavaldón, San Sebastián/Madrid, Festival de San Sebastián/Filmoteca Española, págs. 129-138.

Vila-Matas, Enrique (2002), Bartleby \& compañía, Barcelona, Anagrama. 


\section{Una macabra fábula fantástica}

WiLson, Sheilah R. (1975), «The Fantasy of Bruno Traven: Macario», Latin American Literary Review, 6, págs. 17-21 [En línea: https://www.jstor.org/stable/20118957?seq=1. Fecha de consulta: 07/05/2020].

Fecha de recepción: 14/05/2020.

Fecha de aceptación: 25/07/2020. 